\title{
КОРРОЗИОННОЕ РАЗРУШЕНИЕ И МЕТОДОЛОГИЯ РЕСТАВРАЦИИ АРХЕОЛОГИЧЕСКОГО СВИНЦА
}

\author{
(C) 2021 г. С.Г. Буршнева
}

Подбор метода реставрации археологических предметов напрямую зависит от их состояния сохранности. Подбор адекватного метода реставрации свинцовых предметов усложняется необходимостью делать выбор между сохранением материальной субстанции памятника и его историческим обликом, потому что все известные на сегодняшний день методы стабилизации активной коррозии на археологическом свинце неизбежно приводят к утрате всех минеральных корок и окисных пленок, что негативно сказывается на восприятии предметов и искажает их исторический облик. Предлагаемая в статье классификация сохранности свинцовых предметов и обзор методов реставрации призваны помочь реставраторам минимизировать возможные негативные последствия при выстраивании стратегии реставрации.

Ключевые слова: археологический свинец, консервация археологических находок, методология реставрации металла.

\section{ARCHAEOLOGICAL LEAD CORROSION AND RESTORATION METHODOLOGY}

\section{S.G. Burshneva}

The selection of a method for the restoration treatment of archaeological objects directly depends on their condition. The selection of an adequate method for the restoration of lead objects is complicated by the need to choose between the preservation of the material substance of the object and its historical appearance. All currently known methods of stabilizing active corrosion on archaeological lead inevitably result in the loss of all mineral crusts and oxide films, which negatively affects the perception of the objects and distorts their historical appearance. The classification of the preservation states of lead objects and a review of the restoration methods proposed in the paper are designed to aid restorers in the minimization of possible negative consequences when developing a restoration strategy.

Keywords. archaeological lead, conservation of archaeological finds, metal restoration methodology.

С точки зрения реставрации, археологической сохранностью обладают все предметы, длительное время пролежавшие в земле или под водой. К реставраторам археологического металла поступают не только находки из раскопок, но и предметы, обнаруженные поисковыми отрядами в воинских захоронениях, выкопанные в огородах, поднятые с морского дна, найденные в болотах и пр. Среди свинцовых предметов, поступивших на реставрацию, могут быть античные свинцовые письма, византийские моливдовулы, древнерусские вислые печати, рыболовные снасти, культовые предметы, пули и многое другое. Объединяет их то, что все они подверглись той или иной степени минерализации, и стратегия реставрации таких предметов будет строиться исходя из того, как глубоко зашел этот процесс на каждом предмете. Вторым, не менее важным фактором, на который обращается внимание при выборе метода обработки каждого изделия из свинца - это наличие или отсутствие активной коррозии.

В настоящей статье предлагается схема сохранности археологических предметов из свинца, разработанная с учетом более чем тридцатилетнего опыта работы с археологическим металлом. Схема составлена на основании наблюдений за сохранностью свинцовых предметов из археологических раскопок, проводимых в разные годы в Причерноморье, на Русском Севере, в Республике Карелия и в Республике Татарстан, рассматривались также предметы из частных коллекций. Предметы из археологических раскопок хранятся в фондах Государственного Эрмитажа, Кунсткамеры, Музея археологии АН РТ, Казанском Кремле, Болгарском музее-заповеднике, музее-заповеднике «Херсонес Таврический», Белозерском краеведческом музее.

Как и другие металлы, в погребенных условиях под действием окружающей среды 
свинец подвергается коррозионному разрушению, в результате которого происходит процесс постепенного замещения металла его продуктами коррозии. Находясь неподвижно в погребенных условиях в течение сотен, а иногда тысяч лет, продукты коррозии не выводятся за пределы зоны реакции, а формируются в плотные компактные минеральные (коррозионные) корки, в той или иной мере сохраняющие форму предмета - происходит минерализация металла. В зависимости от того, насколько оказывается агрессивна окружающая среда по отношению к металлу, археологические находки из свинца могут быть покрыты тонкой окисной пленкой, или же частично или полностью минерализованы.

Впервые схему минерализации археологических находок из свинца предложила Дж.М. Кронин в 1990 г. (Cronyn, 1990, 205). Согласно ее схеме, археологические изделия из свинца могут находиться в одной из трех степеней сохранности (минерализации). Свинцовые предметы первой степени сохранности покрыты тонкой окисной пленкой, минерализации как таковой не наблюдается. Во второй степени сохранности оригинальная поверхность остается металлической, только слегка поврежденной коррозионными процессами; на поверхности металла присутствуют продукты коррозии или конкреции различной толщины. При третьей степени оригинальная поверхность присутствует уже в минерализованном состоянии и состоит из продуктов коррозии; если металлическое ядро и сохранилось, оно все разрезано трещинами. По наблюдениям Дж.М. Кронин, на свинцовых археологических предметах, в отличие от других металлов, в процессе минерализации оригинальная поверхность не сохраняется, все топографические детали отображаются на внешней поверхности минеральной корки (Cronyn, 1990, 204). Удаление полностью или частично минеральных корок со свинца может привести к утрате изображения.

В целом соглашаясь с классификацией сохранности археологического свинца Дж.М. Кронин, мы предлагаем более подробное описание каждой стадии. Схема минерализации археологического свинца с примерами сохранности приведена в таблице.

Сохранность археологического свинца
В силу своей природы свинец демонстрирует хорошую сопротивляемость коррозии во всех природных средах благодаря образованию на его поверхности плотной компактной защитной пленки. Как следствие, свинцовые предметы в процессе археологизации могут практически не подвергаться минерализации, в результате чего мы извлекаем из раскопок предметы из свинца, покрытые только окисной пленкой - патиной, поверх которой могут присутствовать различные почвенные наслоения или конкреции, если свинец пролежал в морской воде. Это первая степень сохранности археологического свинца, которую мы обозначили $\boldsymbol{P b}$-1. Если коррозионные минералы окисной пленки формируются медленно, то пленка получается компактная, хорошо прилегающая к металлу и вследствие этого выполняющая защитную функцию. Белые или бесцветные пленки на поверхности археологического свинца обычно состоят из карбоната свинца(II) церуссита $\mathrm{PbCO}_{3}$. Свинцовые предметы с такими пленками находят во влажных известковых почвах или в морской воде. Эти пленки могут включать белые сульфаты свинца(II) англезит $\mathrm{PbSO}_{4}$ или ледгиллит $\mathrm{Pb}_{4}\left(\mathrm{SO}_{4}\right)\left(\mathrm{CO}_{3}\right)_{2}(\mathrm{OH})_{2}$, в пленках из морской воды может присутствовать фосгенит $\mathrm{Pb}_{2}\left(\mathrm{CO}_{3}\right) \mathrm{Cl}_{2}$ и другие хлориды свинца(II) (Cronyn, 1990, 202). Как правило, никаких коррозионных наростов и «бородавок», пустул, на таких предметах не имеется. В относительно сухих аэрированных условиях пленки, обычно бесцветные, коричневато-желтоватые или бежевые. Такая цветовая гамма возникает, скорее всего, если в формировании пленок участвуют оксиды свинца(II) глет и массикот $\mathrm{PbO}$ или хлорид свинца(II) коттунит $\mathrm{PbCl}_{2}$. Черный цвет пленкам обычно придают сульфид свинца(II) галенит $\mathrm{PbS}$ . Этот минерал обнаружен на предметах из полузатопленных городских раскопов (Duncan et al., 1987, 108).

Ко второй степени сохранности $\boldsymbol{P} \boldsymbol{b}$-2 относятся предметы, где процесс минерализации можно диагностировать невооруженным глазом. Тонкая минеральная корка покрывает металлическое ядро равномерно, ее толщина не превышает 0,5 мм. Различить ее можно по местам утрат. В случае полной утраты минеральной корки на этой стадии сохранности существенного ущерба памятнику не 
Таблийа 1

\section{СТАДИИ СОХРАННОСТИ АРХЕОЛОГИЧЕСКОГО СВИНЦА}

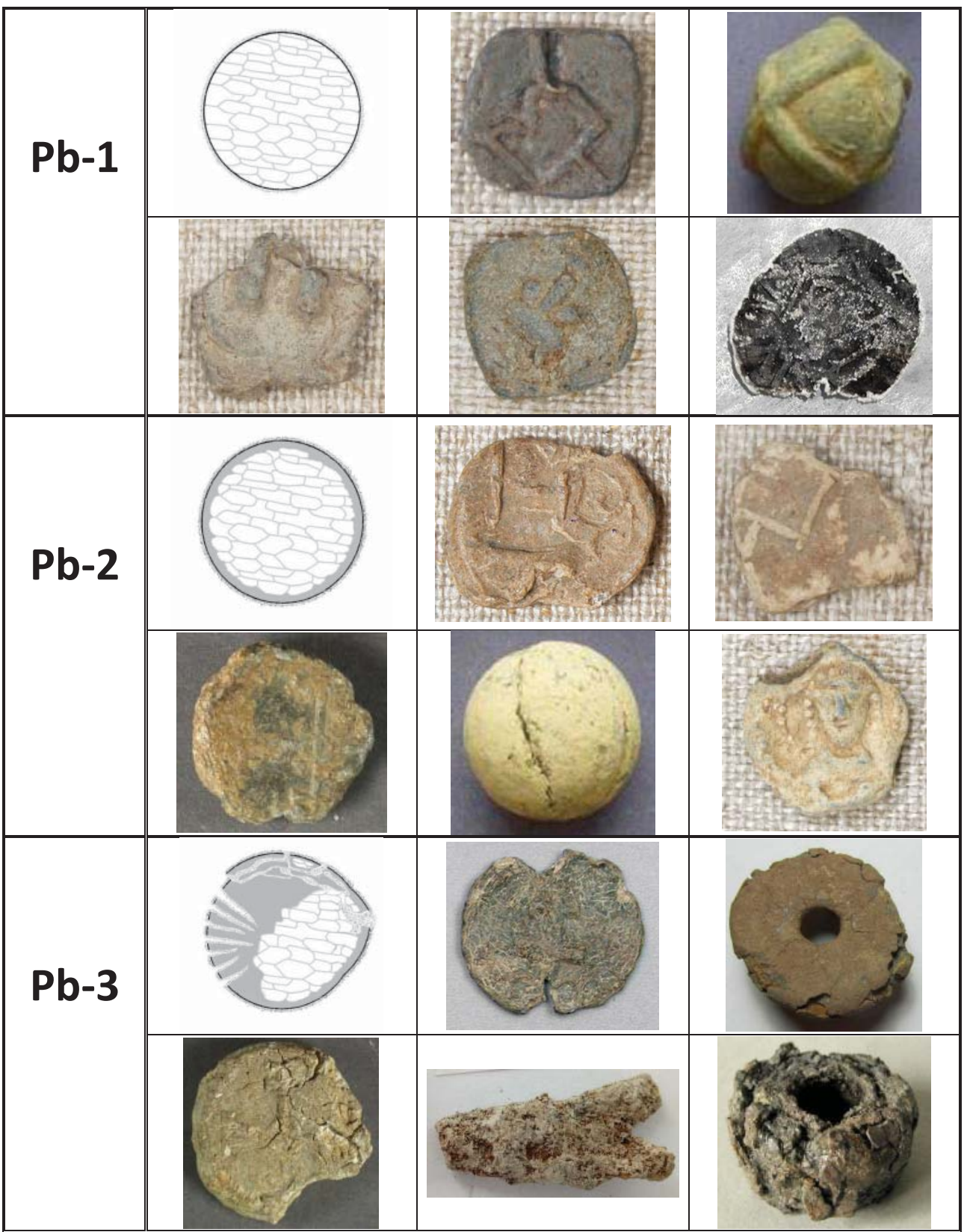

произойдет, но его поверхность уже не будет отражать изначальную. Утраты минеральной корки могут произойти еще в процессе археологизации предмета, поверхность металла в этом случае будет неровной, как бы потравленной коррозией. Образовавшиеся минеральные корки могут равномерно покрывать свинцовый предмет, или присутствовать только частично, оставляя часть поверхности покрытой окисной пленкой. Очень неравномерная минерализация вообще является особенностью археологизации предметов из свинца. Минеральные корки на пред- метах бывают плотные, насыщенного цвета с глянцевым блеском. Такие корки, если они не повреждены, очень хорошо предохраняют металлическое ядро от воздействия окружающей среды. Корки могут быть полностью рыхлые, осыпающиеся, практически не отражающие особенности рельефа и не защищающие металл. Однако большинство свинцовых предметов на этой стадии сохранности имеют тусклые коричневато-серые неплотные и слегка бугристые корки, часто покрытые трещинами или небольшими коррозионными наростами. Сквозь поры и трещины 
таких минеральных корок относительно легко просачиваются влага и пары углекислоты и провоцируют развитие активной коррозии. Что касается минералогического состава и цветовой гаммы минеральных корок, то они во многом совпадают с окисными пленками. Белые или серые коррозионные корки на свинцовых предметах также состоят из церуссита или гидроцеруссита $\mathrm{Pb}_{3}\left(\mathrm{CO}_{3}\right)_{2}(\mathrm{OH})_{2}$, но могут быть окрашены в разные цвета другими соединениями свинца: розовато-фиолетовые, красные и коричневые тона дают глёт и ортоплюмбат свинца(II) свинцовый сурик $\mathrm{Pb}_{3} \mathrm{O}_{4}$, желтые тона обеспечивает массикот, коричневые - оксид свинца(IV) платтнерит $\mathrm{PbO}_{2}$, серый оттенок придают включения черного галенита. Черный или глубокий золотистый цвет свинцовых изделий образуется в анаэробных условиях в результате деятельности серобактерий, при этом не важно, находятся предметы в почве или морской воде. Свинец чернеет из-за образования на поверхности сульфида свинца галенита.

К стадии сохранности $\boldsymbol{P} \boldsymbol{b}-3$ мы относим предметы, подвергшиеся глубокой или полной минерализации. На этой стадии по-прежнему встречаются предметы только частично минерализованные, однако минерализовавшиеся участки уже довольно глубоко проникают вглубь предмета. Процесс минерализации сопровождается образованием коррозионных наростов - пустул, и растрескиванием минеральных корок, что ведет к искажению формы предметов и многочисленным утратам не только оригинальной поверхности, но и целых фрагментов. Пустулы чаще всего образуются, если в состав минеральных корок в процессе коррозии оказываются включены твердые частицы окружающего грунта. Растрескивание минеральных корок и их деформация является, вероятно, следствием межкристаллитной коррозии свинца, при которой на металле появляются разрывы, заполненные рыхлыми продуктами коррозии, минерализация же просто сохраняет уже появившиеся разрывы. В целом свинцовые предметы не склонны к сильному увеличению в объеме в процессе минерализации, их минеральные корки остаются довольно компактными, за исключением случаев сильного растрескивания. По наблюдениям Дж.М. Кронин, такие минеральные корки состоят из карбонатов и гидрокарбонатов свинца и формируются только в щелочных почвах, так как карбонаты склонны растворяться в кислых условиях (Cronyn, 1990, 204). По нашим наблюдениям сильное растрескивание предметов, сопровождающееся слабой минерализацией, может произойти и в кислых условиях. При этом формируются рыхлые продукты коррозии белого цвета, не способные удерживать фрагменты друг с другом, и металлическое ядро сохраняется в каждом отделившемся от основной массы фрагменте (рис. 1).

На свинцовых предметах подтвердить полную минерализацию металла не разрушая предмет практически невозможно, даже рентгенографическое исследование может дать неточные результаты. Поэтому мы не выделяем полностью минерализованные свинцовые предметы в отдельную стадию, но предполагаем, что она может закономерно наступить в процессе археологизации. Мы склонны думать, что полностью минерализованные свинцовые предметы могут просто не идентифицироваться, полностью рассыпаясь в шлам. Дж.М. Кронин описывает возможность такого развития событий для свинца, подвергшегося коррозии в присутствии серобактерий с образованием галенита (Cronyn, 1999, 204). Тем не менее, полностью минерализованные и вследствие этого исключительно хрупкие свинцовые предметы могут встречаться во время археологических раскопок. Фотографию фрагмента полностью минерализованной свинцовой печати приводит М.С. Шемаханская (Шемаханская, 2015,134). Не исключено, что рассыпающиеся частицы таких предметов удерживаются друг с другом системой мелких корешков, грунта и влаги, благодаря чему форма предметов сохраняется, но только до того момента, как влага начнет испаряться, а грунт и корешки сохнуть.

На археологическом свинце может развиваться активная коррозия, которая проявляется путем образования белых порошковых коррозионных образований на поверхности, в порах и трещинах предметов - карбонат свинца (минерал церуссит) и основной карбонат свинца (минерал гидроцеруссит). Подробному разбору механизма активной коррозии свинца посвящена отдельная статья данного сборника. Свинцовые предметы могут пострадать от активной коррозии еще в погребенных усло- 


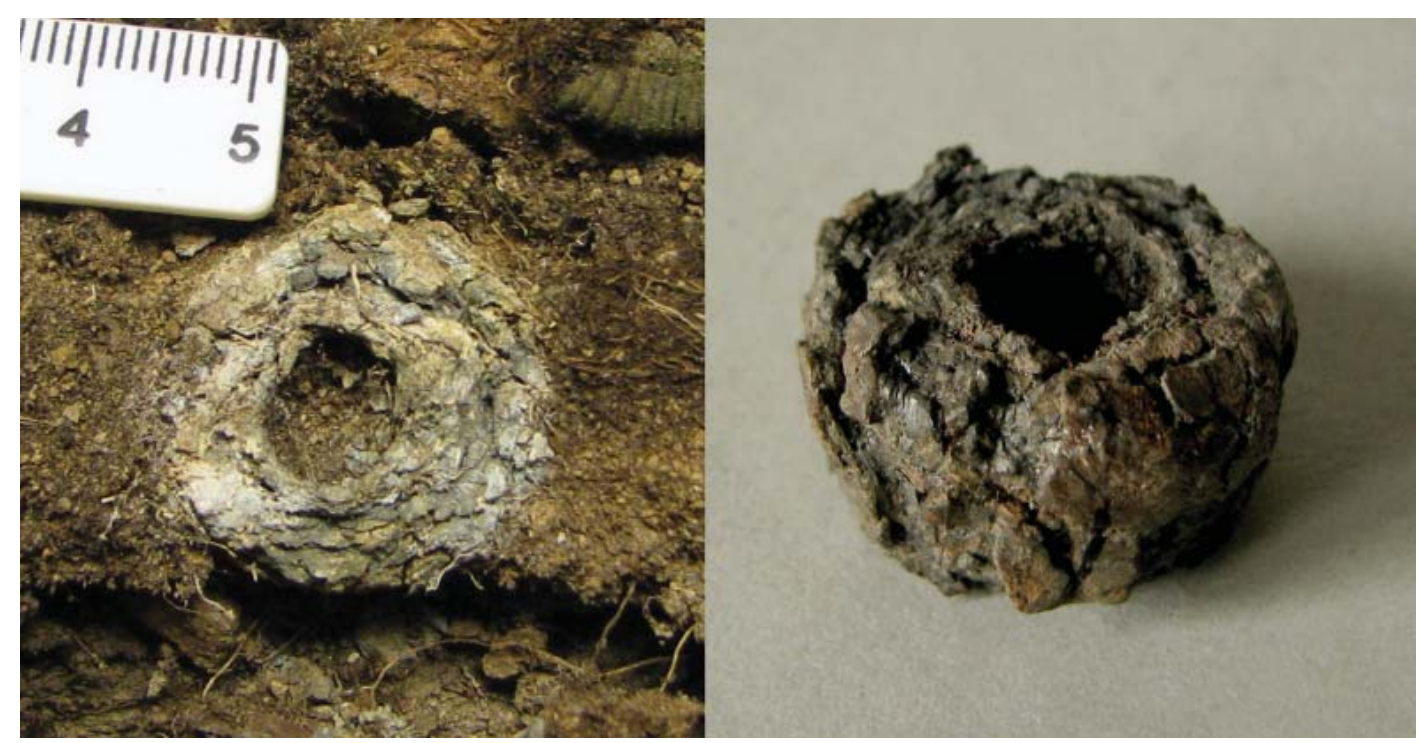

Рис. 1. Растрескивание и расслоение свинца в кислых почвах: в погребенных условиях и после консервации. Фото С.Г. Буршневой

Fig. 1. Cracking and stratification of lead in acidic soils: in buried conditions and after conservation. Photo by S. G. Burshneva

виях, о чем свидетельствуют коррозионные язвы на поверхности, заполненные рыхлыми белыми образованиями, часто уплотнившимися и приобретшими желтоватый оттенок в процессе залегания. Иногда белые порошковые образования покрывают практически всю поверхность предмета. Сами по себе порошковые церуссит и гидроцеруссит не представляют опасности для предметов. Порошковая форма этих минералов, которая образуется вследствие высокой скорости коррозионных процессов, свидетельствует о наличии активатора коррозии в ближайшем пространстве, окружающем свинцовый предмет, а также в порах, трещинах и рыхлых коррозионных образованиях на самом предмете. Активаторами коррозии для свинца в погребенных условиях могут служить органические кислоты, содержащиеся в почвах; в постраскопочный период к органическим кислотам (пары которых часто присутствуют в атмосфере) добавляется также углекислый газ. В отличие от археологических железа и бронзы, активатор коррозии свинца в основном содержится не в минеральных корках предметов, а в окружающей среде.

Как и большинство археологических предметов, свинец остро нуждается в реставрационном вмешательстве. Существующая в настоящее время методология реставрации археологического свинца включает методы очистки, стабилизаџии и консерваџии.

\section{Методы очистки археологического свинца}

В публикации1935 г. А. Скотт рекомендует удалять локальные образования карбонатов с поверхности свинцовых предметов разведенными кислотами (уксусной, азотной или соляной) с кисти (Скотт, 1935, 41). Применение химических методов очистки автор оправдывает только для предметов, где необходимо выявить изображение. При этом все минеральные корки с предметов удаляются, сам металл в процессе обработки может быть поврежден. В 1953 году Р.М. Орган предложил удаление карбонатов и хлоридов с поверхности свинца с помощью ионообменных смол (Organ, 1953, 49-52). Этот метод позже был описан и в работе Г.Дж. Плендерлиса в русском переводе 1964 г. (Плендерлис, 1964, 82-86). Авторы считают, что при такой обработке металл не страдает, а наслоения из основного карбоната свинца удаляются: ионы свинца замещаются на ионы водорода при одновременном выделении углекислого газа из горячей жидкости. Однако при использовании метода необходимо учитывать, что в дистиллированной воде свинец очень медленно, но все-таки растворяется, что может привести к легкому сглаживанию рельефа. Среди других методов очистки Г.Дж. Плендерлис рекомендует обработку предметов в сильно разбавленной соляной кислоте с последующей нейтрализацией ацетатом аммония (Плендерлис, 1964, 81-82). 
Этот метод рекомендован Р. Кэли как хорошо зарекомендовавший себя: пятьдесят шесть свинцовых предметов из Агора, обработанные таким образом, через 17 лет сохранились в отличном состоянии (Caley, 1955, 49-54). В 1976 году Дж. Ватсон, вслед за немецкими реставраторами, применил и описал метод очистки свинцовых предметов с помощью комплексообразователей, в частности динатриевой соли EDTA (этилендиаминтетрауксусной кислоты), в российской реставрации известной как Трилон Б, разбавленной до 10\% по объему (Watson, 1985, 44-45). Метод описан для свинцовых предметов, покрытых активными образованиями основного карбоната свинца. Метод очистки комплексообразователями эффективен для минеральных корок сложного состава, однако его недостаток состоит в том, что эти растворы способны атаковать металлическое ядро предмета после того, как будут удалены продукты коррозии. Особенно опасно применение комплексообразователей для тех предметов, поверхность которых покрыта неравномерными коррозионными образованиями. Дж. Ватсон отметил, что комплескообразователи практически не воздействуют на оксид свинца(II) - глет. Автор рекомендует применять Трилон Б для очистки свинцовых предметов в следующих случаях: 1) на сильно минерализованных предметах с целью избежать утрат деталей поверхности; 2) на свинцовом стекле; 3) на свинцовых деталях на органических материалах, особенно сочетающихся с деревом: Трилон Б не оказывает какого-либо действия на древесину (Watson, 1985, 45). Некоторые реставраторы применяют раствор Трилона Б локально для очистки отдельных участков (Курганов, 2017, 366). Против применения Трилона Б возражает Дж.М. Кронин, ссылаясь на то, что даже незначительные количества неотмытой после реставрации кислоты могут спровоцировать развитие коррозии (Cronyn, 1990, 207). Применять обработку в Трилоне Б для корродированных свинцовых печатей, прикрепленных шнуром к документам, рекомендует М.С. Шемаханская (Шемаханская, $2015,221)$. В настоящее время для очистки свинцовых предметов следует отдавать предпочтение механическим способам (Cronyn, 1990, 208).
Методы стабилизации археологического свинца

Методы стабилизации направлены прежде всего на устранение причин, вызывающих активную коррозию свинца. Эффект очистки от продуктов коррозии и восстановление окислов до металлического свинца при использовании этих методов является сопутствующим и неизбежным, учитывая, что свинец является мягким металлом и сравнительно легко восстанавливается до металла электрохимическими и электролитическими методами. В 1935 году, основываясь на практическом опыте реставрации музейных предметов, А. Скотт отмечал, что «Проблема в отношении музейных образцов заключается в том, чтобы приостановить раз начавшуюся быструю коррозию» (Скотт, 1935, 40). Основную причину быстрой коррозии свинца А. Скотт видит в поражающем действии жиров и масел, тонкие пленки которых образуются на поверхности музейных предметов в процессе бытования. Для их удаления А. Скотт рекомендует применение двух реагентов: 1) раствора гидроксида натрия с прибавлением метилового спирта; 2) раствор основного ацетата свинца. Предметы рекомендуется нагревать в одном из приведенных растворов, тщательно промывать, затем опять нагревать в растворе ацетата свинца, который содержит свободную уксусную кислоту, после чего опять тщательно промывать.

Одним из первых методов электрохимического восстановления свинцовых предметов был метод восстановления окислов свинца с цинковой пылью в разбавленных азотной (Schotte et al., 2004, 300), серной (Минжулин, $1992,66)$, уксусной (Скотт, 1935, 40) или муравьиной (Фармакрвский, 1947, 82) кислотах. Во всех случаях с разной скоростью имеет место окислительно-восстановительная реакция, при которой восстанавливается металлический свинец, а цинк, соответственно, окисляется. Этот метод имеет ряд недостатков: а) реакция плохо поддается контролю, так как предметы полностью закрыты от обзора; б) при избытке кислоты может начаться растворение металлического ядра; в) удаляются все соединения коррозии свинца, в том числе и выполняющие защитные функции. Данный метод направлен скорее на удаление продуктов коррозии, чем на восстановление металла. 
Нам представляется, что из всех перечисленных кислот наименее опасной для свинцовых предметов является серная кислота, так как способна формировать нерастворимые защитные пленки сульфата свинца на поверхности металла, причиняя наименьший вред в случае избытка. Электрохимическое восстановление окислов в гидроксиде натрия (каустической соде) с металлическим цинком рекомендует Г.Дж. Плендерлис (Плендерлис, 1964, 79-81). Автор обращает внимание, что свинец легко разрушается гидроксидом натрия, и поэтому особое внимание надо уделить отмывке предметов от остатков реагента, так как если щелочь застрянет в пористой поверхности или в трещинах металла, то через некоторое время коррозионный процесс возобновится. Р.М. Орган, описывая применение электрохимического метода восстановления археологических свинцовых предметов в Смитсониевском институте в Вашингтоне, отмечает, что после обработки с применением гидроксида натрия на поверхности предметов могут остаться трудноудаляемые остатки солей цинка (Organ, 1977, 136).

Метод, направленный именно на восстановление свинцовых окислов с сохранением всех деталей изображения, предложил Р.М. Орган в начале 60-х годов XX века (Геттенс и др., 1968, 128-129). Сильно корродированная свинцовая печать XIV века превратилась в карбонат свинца на 2/3 настоящей толщины. Много лет поверхность печати была защищена слоем шеллака, что предотвратило отслоение минеральной корки. Без предварительной обработки был проведен электролиз в 5\% растворе гидроксида натрия. Печать была зажата между двумя подушками из полиуретановой пены железными дисками, которые служили анодами. Электрический контакт с металлическим ядром печати был осуществлен с помощью иглы. Восстановление шло непрерывно в течение трех дней при силе тока $100 \mathrm{MA} /$ дм² $^{2}$ В результате обработки удалось восстановить карбонат в металлический свинец, полностью сохранив форму. Впоследствии данный метод стали называть консолидирующее или укрепляющее восстановление (consolidative reduction). Эту технику применили польские реставраторы для реставрации почти полностью минерализованного свинцового диска из раскопок в Кракове (Nosek,
1985, 21-22). Время обработки свинца при указанных параметрах заняло три месяца, в результате было восстановлено около 95\% коррозионной массы в металлический свинец.

Идея электролитического восстановления продуктов коррозии на свинцовых предметах получила широкое распространение среди реставраторов во всем мире. Проводились эксперименты по подбору оптимальных режимов обработки, электролитов и электродов, исследовалась эффективность электролитической обработки, рассматривались недостатки способа. Р.М. Орган предложил проводить консолидирующее восстановление свинца в 5\% растворе карбоната натрия при силе тока 2-5 A/дм² с анодами из нержавеющей стали или платинированным титаном. После электролитической обработки рекомендуется сначала делать промывку в воде, затем в сильно разбавленной серной кислоте для формирования на поверхности предмета защитной пленки сульфата свинца (Organ, 1977, 136). Британскими реставраторами проводилось тестирование различных методов электролитической очистки свинцовых изделий в плане их воздействия на металлическое ядро (Lane, 1989, 48-58). Тестирование проводилось путем взвешивания образцов через определенные промежутки времени. Самым эффективным электролитом был признан 5\% карбонат натрия, так как он образует защитную пленку на поверхности предметов в процессе обработки, в результате чего растворение металла в этом растворе минимально. Автор публикации отмечает, что до определенной степени свинец растворяется во всех электролитах. Автор также обращает внимание, что восстановление металлического свинца происходит из карбонатов свинца, из оксида свинца восстановление металла происходит только в том случае, если под оксидом присутствует в достаточном количестве карбонат свинца. Если свинец в процессе минерализации сильно пострадал от межкристаллитной коррозии, то при попытке провести консолидирующее восстановление на таких предметах последние могут осыпаться мелкими чешуйками на дно контейнера (Lane, 1989, 57). Применять консолидирующее восстановление реставраторы считают целесообразным только на тонких хрупких предметах. Сравнение различных электролитов проводили также 
С. Дегрини и Р. Ле Галл в 1999 г. (Degriny et al., 1999, 157-169). Из четырех тестируемых электролитов (гидроксид натрия, карбонат натрия, серная кислота и сульфат натрия) авторы рекомендуют сульфат натрия как наименее активный и безопасный для металлического свинца при электролитической обработке. В 1994 году британские реставраторы предложили так называемый метод потенциостатического восстановления (potentiostatic reduction), примененный для реставрации коллекции жетонов причастия из собрания университета Сент-Эндрю в Шотландии (Carradice et al., 1994, 103). Этот электролитический метод разработан для реставрации одновременно нескольких свинцовых предметов. Предварительно обезжиренные, промытые в дистиллированной воде и просушенные жетоны подвешивались на свинцовых лентах около 1 см шириной в $0,5 \mathrm{M}$ раствор серной кислоты. Все жетоны были объединены в систему и помещены в электролитическую ванну с напряжением 1,2В на 30-40 минут. Авторы считают, что таким образом можно стабилизировать активную коррозию на предметах.

В отечественной школе реставрации свинца наиболее эффективным признана комбинированная методика электролитического/ электрохимического восстановления продуктов коррозии, разработанная в Государственном Эрмитаже химиком Н.Г. Герасимовой и реставратором высшей категории Н.A. Панченко в 60-х годах XX века (Герасимова и др., 2017, 5-12). Взяв за основу метод консолидирующего восстановления Р.М. Органа, специалисты Государственного Эрмитажа провели серию экспериментов по подбору оптимальных параметров электролитического восстановления. Эксперименты проводились на моделях, изготовленных из технического свинца, покрытых слоем свинцовых белил толщиной около 2 мм, пигмент замешивался и накладывался на пластины с помощью водноспиртового раствора поливинилбутираля (ПВБ). При электролитическом восстановлении в качестве электролита использовались растворы гидроксида натрия, соды $\mathrm{Na}_{2} \mathrm{CO}_{3}$ и серной кислоты. Анодами в щелочных растворах служила нержавеющая сталь, в кислоте свинец. Электрохимическое восстановление проводилось в растворах муравьиной и серной кислот с пластинками цинка. По результатам эксперимента авторы пришли к ряду важных выводов, сделанных на основе наблюдений в ходе эксперимента и последующем исследовании образцов. Отмечено, что восстановление карбоната свинца в металлический свинец по всему слою белил происходит только после электролитического восстановления; при электрохимической обработке восстанавливается только поверхностный слой карбоната. Электролитическое восстановление можно проводить при большей плотности тока, чем рекомендовано другими исследователями, и в этом случае восстановление идет быстрее и обработку можно закончить в течение одного дня. Авторы рекомендуют плотность тока 1-2 $\mathrm{A} /$ дм$^{2}$ в щелочном электролите. Для сокращения срока промывания после электролитического восстановления в щелочной среде авторы исследования рекомендуют применять электрохимическую обработку с использованием кислоты и цинка, отдавая предпочтение серной кислоте (Герасимова и др., 2017, 10). В результате проведенных исследований в Государственном Эрмитаже была выработана эффективная комбинированная методика стабилизации и последующей консервации свинцовых печатей, сочетающая электролитическое восстановление окислов с последующей электрохимической обработкой. Для обработки свинцовых печатей рекомендованы следующие процессы: катодное восстановление в растворе гидроксида натрия при плотности тока 1-2 A/дм², последующее получасовое восстановление с использованием цинка и $10 \%$-ной серной кислоты, промывание проточной водопроводной водой до нейтральной реакции, удаление воды выдерживанием в трех сменяемых ацетоновых ваннах по 30 минут и консервирующая пропитка непосредственно из третьей ацетоновой ванны в расплаве микрокристаллического воска (Герасимова и др., 2017, 11). Данная методика с незначительными изменениями применяется в Государственном Эрмитаже более 50 лет.

\section{Методы консервации археологического свинца}

В качестве защитного покрытия предметов из свинца разные авторы рекомендуют пленочные полимерные составы или различные восковые композиции. А. Скотт рекомендует использовать для консервации свинцовых предметов даммарный лак (Скотт, 
1935, 43). М.Ф. Фармаковский настаивает на необходимости консервировать свинец в горячем воске, целлюлозный лак и парафин он считает непригодными для консервации (Очерки, 1935, 120). В другой работе этот же автор предлагает уже два возможных способа - шеллаковую смолу или растопленный воск (Фармаковский, 1947, 82). Г.Дж. Плендерлис и Р.М. Орган консервацию рекомендуют проводить в расплаве парафина (Плендерлис, 1964, 82; Organ, 1977, 135). А.И. Минжулин, помимо консервации в расплаве парафина, рекомендует использовать восковые композиции с полиэтиленгликолем молекулярной массы от 500 до 1000, где ПЭГ служит пластификатором, а также композиции с бензотриазолом в качестве ингибитора (Минжулин, 1992, 66). В последние годы в качестве защитного покрытия чаще всего применяется раствор Паралоида B-72 и другие акриловые полимеры (Bellegem, 2010, 352; Курганов, 2017, 366).

В рамках проекта по защите свинцовых органных труб в церквях Европы было проведено тестирование различных консервационных покрытий на предмет их сопротивляемости коррозии в условиях постоянной эманации в атмосферу какого-то количества органических кислот от деревянных деталей органов (Aslund et al., 2007, 16-22). Тестированию подвергались образцы свинца, обработанные раствором Паралоида В-72 и образцы, покрытые микрокристаллическим воском. Ускоренный коррозионный тест с парами уксусной кислоты не дал удовлетворительных результатов: коррозия возобновилась во всех случаях (Aslund et al., 2007, 20). Более эффективной для защиты свинцовых деталей органов оказалась обработка деревянных частей наночастицами гидроксида кальция (погружение в спиртовой раствор на 24 часа). Данная обработка существенно снизила эманацию органических кислот в атмосферу, что в итоге способствовало лучшей сохранности свинца. Наблюдения велись в течение 13 месяцев (Aslund et al., 2007, 21).

В 1972-1975 гг. Государственным Эрмитажем совместно с лабораторией ингибиторов коррозии ВНИИ Нефтехим (Ленинград) были проведены исследования по совершенствованию методов консервации музейного свинца. По результатам испытаний для консервации свинцовых печатей был рекомендован инги- бированный состав на основе ультрамида $1 \mathrm{C}$. Однако несмотря на хорошие результаты во время испытаний, ни одно из тестируемых полимерных покрытий не проявило удовлетворительной устойчивости в реальных условиях хранения (Герасимова и др., 2017, 10). В результате дальнейшей работы по поиску возможных консервационных покрытий был протестирован микрокристаллический воск Космоллоид (Cosmolloid 80H). Испытания покрытия проводились в камере с коррозионной средой, содержащей в газовой фазе углекислый газ, уксусную кислоту и влагу. Для сравнения в камеру с тестируемыми образцами покрытия помещался и незащищенный свинец, который уже на третий день покрывался серо-белым слоем солей. На образцах с тестируемым консервационным покрытием белый налет появлялся в местах дефектов защитного покрытия. В результате экспериментального исследования была отработана методика нанесения консервационного покрытия из микрокристаллического воска. Консервация свинцовых печатей в расплаве микрокристаллического воска марки Cosmolloid $80 \mathrm{H}$ было признано наиболее эффективным для длительного хранения (Герасимова и др., 2017, 11).

Как и для всех археологических предметов из металла, в процессе реставрации свинцовых находок предпочтение следует отдавать механическим методам расчистки, избегая по возможности применения химических реактивов и водных методов очистки. Механические способы очистки свинцовых предметов эффективны, когда поверхность, независимо от степени минерализации, покрыта только рыхлыми, сравнительно легко удаляемыми коррозионными образованиями, и на предметах отсутствуют проявления активной коррозии. При наличии признаков активной коррозии применение водно-механической обработки, химических или электрохимических способов очистки является вынужденной мерой, так как удалить активатор коррозии только механическими методами невозможно. Однако применение химических и электрохимических методов очистки и стабилизации свинцовых предметов полностью уничтожает естественным образом сформировавшиеся окисные пленки и минеральные корки, оставляя после реставрации блестящий металл. 
Это негативно сказывается на восприятии предметов, искажает их исторический облик - археологические предметы более не выглядят таковыми. Но изображение при этом читается без каких-либо проблем, не искажаемое коррозионными образованиями.

Для сохранения не только самих свинцовых предметов, но и подлинного археологического облика этих предметов, самым эффективным способом предотвращения развития активной коррозии является обеспечение специальных условий хранения и экспонирования. Свинцовые предметы следует хранить в герметично закрывающихся упаковках, емкостях и витринах из химически инертных материалов, исключающих попадание к артефактам паров органических кислот и углекислого газа. Только полная изоляция предметов от указанных активаторов коррозии может гарантировать невозобновление активной коррозии.

\section{ЛИТЕРАТУРА}

Герасимова Н.Г., Панченко Н.А. Реставрация и консервация свинцовых печатей в Государственном Эрмитаже // Реликвия. Реставрация, консервация, музеи. 2017. № 34. С. 5-12.

Геттенс Р.Дж., Орган Р.М. Электролитическая и электрохимическая обработка минерализовавшегося металла (опрос) // Доклады иностранных специалистов, прочитанные на конференции комитета по лабораториям музеев и подкомитета по реставрации живописи международного совета музеев, состоявшейся в сентябре 1963 г. / Сообщения ВЦНИИЛКР, Приложение 3. Вып. 3. М.: ВЦНИИЛКР, 1968. $137 \mathrm{c}$.

Курганов Н.С., Горлов К.В. Цветные наслоения на поверхности средневековых товарных пломб: исследования в процессе реставрации // Stratum plus. 2017. № 6. С. 361-370.

Минжулин А.И. Введение в реставрацию металла. Учебно-методическое пособие. Киев: КВИУС, 1992, $100 \mathrm{c}$.

Очерки по методике технологического исследования, реставрации и консервации древних металлических изделий / ИГАИМК. Вып. 130. М.-Л.: ОГИЗ, 1935. 121 с.

Плендерлис Г.Дж. Консервация древностей и произведений искусства. Пер. с англ. И.А. Токмаковой, И.П. Мокрецовой и М.Н. Иванова, под общ ред. д.х.н. С.А. Зайцева / Сообщения ВЦНИИЛКР 10-11. Вып. 3. М.: ВЦНИИЛКР. 1964. 176 с.

Скотт A. Очистка и реставрация музейных экспонатов. Пер. с англ. В.А. Фроловой и В.Е. Фармаковской / ИГАИМК. ВЫп. 114. М.-Л.: ОГИЗ, 1935. 72 с.

Фармаковский М.Ф. Консервация и реставрация музейных коллекций. М.: Красный печатник, 1947. $144 \mathrm{c}$.

Шемаханская М.С. Металлы и вещи. История. Свойства. Разрушение. Реставрация. М: Индрик. 2015. $288 \mathrm{c}$.

Aslund A., Bergsten C.J., Chiavari C., Martini C., Niklasson A., Prandstraller D., Svensson J-E. Conservation strategies against the corrosion of historical pipe organs // Metal 07: Interim Meeting of the ICOM-CC Metal WG Amsterdam, 17-21 September 2007. Book 5. Protection of metal artefacts / Amsterdam: Rijksmuseum, 2007. P. 16-22.

Bellegem M., Wang Q., Fletcher P. A scientific study and preliminary experiments for electrolytic reduction of corroded lead inlay on Japanese lacquer objects // Metal 2010, Proceedings of the Interim Meeting of the ICOM-CC Metal Working Group, Charleston, South Carolina, USA,11-15 October 2010 / Edited by Paul Mardikian, Claudia Chemello, Christopher Watters and Peter Hull / Clemson: Clemson University, 2011. P. 348-356.

Caley $R$. Coatings and incrustations on lead objects from Agora and the method used for their removal // Studies in Conservation. 1955. № 2. P. 49-54.

Carradice I.A., Campbell S.A. The conservation of lead communion tokens by potentiostatic reduction // Studies in Conservation. 1994. № 39. P. 100-106.

Cronyn J.M. The Elements of Archaeological Conservation. London: Routledge, 1990. 326 p.

Degrigny, C., and Le Gall, R. Conservation of ancient lead artefacts corroded in organic acid environments: electrolytic stabilization/consolidation // Studies in Conservation. 1999. №44. P. 157-169.

Duncan S.J., Ganiaris H. Some sulfide corrosion products on copper alloys and lead alloys from London waterlogged sites // Recent Advances in the Conservation and Analysis of Artifacts: Jubilee Conservation Conference Papers / Edited by James Black / Michigan: Summer Schools Press, 1987. P. 109-117. 
Lane H. Some comparisons of lead conservation methods, including consolidative reduction // The Conservation and Restoration of Metals / Scottish Society for Conservation and Restoration. Edinburgh, 1979, P. $48-58$.

Nosek E.M. The investigation and conservation of a lead paten from the eleventh century // Studies in Conservation 30, 1985, 19-22.

Organ, R.M. Use of ion-exchange resins in the treatment of lead objects. // Museums Journal. 1953. No 53. 49-52.

Organ, R.M. The current status of the treatment of corroded metal artifacts. // Corrosion and Metal Artefacts. Special publication 179 / Brown, B.F., Burnett, H.C., Chase, W.T., Goodway, M., Kruger, J., and Poubaix, M. (eds). Washington, D.C.: National Bureau of Standards, 1977, P. 107-142.

Schotte B., Adriaens A. Treatment of corroded lead artifacts: an overview // Studies in conservation 2006. № 51. P. 297-304.

Watson J. Conservation of lead and lead alloys using E.D.T.A. solutions // Lead and Tin: Studies in Conservation and Technology / UKIC Occasional Paper № 3. London: United Kingdom Institute for Conservation, 1985. P. 44-45.

\section{Информация об авторе.}

Буршнева Светлана Георгиевна, художник-реставратор высшей категории, Государственный Эрмитаж (г. Санкт-Петербург, Россия); младший научный сотрудник, Институт археологии им. А.Х. Халикова АН РТ (г. Казань, Россия); burshneva@yandex.ru

\section{REFERENCES}

Gerasimova, N. G., Panchenko, N. A. 2017. In Relikviia. Restavratsiia, konservatsiia, muzei (Relics. Restoration, Conservation, Museums) 34, 5-12 (in Russian).

Gettiens. R. J., Organ, R. M. 1968. In Soobshcheniia VCNIILKR (Proceedings of VTsNILKR) 3 (in Russian).

Kurganov, N. S., Gorlov, K. V.. 2017. In Stratum plus. Archaeology and Cultural Anthropology (6), 361-370 (in Russian).

Minzhulin, A. I. 1992. Vvedenie v restavratsiiu metalla (Introduction to Metal Restoration). Kiev: "KVIUS" Publ. (in Russian).

1935. Ocherki po metodike tekhnologicheskogo issledovaniia, restavratsii $i$ konservatsii drevnih metallicheskih izdelii (Essays on the Methodology of Technological Research, Restoration and Conservation of Ancient Metal Objects). Series: Izvestiia Gosudarstvennoi Akademii istorii material'noi kul'tury (Bulletin of the State Academy for the History of Material Culture) 130. Leningrad: "OGIZ" Publ. (in Russian).

Plenderluis, G. J. 1964. (Konservatsiia drevnostei i proizvedenii iskusstva (Conservation of Antiquities and Works of Art). Moscow (in Russian).

Skott, A. 1935. Ochistka i restavratsiia muzenykh eksponatov (Cleaning and Restoration of Museum Exhibits). Series: Izvestiia Gosudarstvennoi Akademii istorii material'noi kul'tury (Bulletin of the State Academy for the History of Material Culture) 114. Leningrad: "OGIZ” Publ. (in Russian).

Farmakovsky, M. F. 1947. Konservatsiia i restavratsiia muzeinykh kollektsii (Conservation and Restoration of Museum Collections). Moscow: "Krasny pechatnik" Publ. (in Russian).

Shemakhanskaya, M. S. 2015. Metally i veshhi. Istoriya. Svoystva. Razrushenie. Restavratsiya (Metals and Articles. History. Properties. Destruction. Restoration). Moscow: "Indrik" Publ. (in Russian).

Aslund A., Bergsten C. J., Chiavari C., Martini C., Niklasson A., Prandstraller D., Svensson J-E. 2007. In Metal 07: Interim Meeting of the ICOM-CC Metal WG Amsterdam, 17-21 September 2007. Book 5. Protection of metal artefacts. Amsterdam: Rijksmuseum, 16-22.

Bellegem M., Wang Q., Fletcher P. A 2011. In Paul Mardikian, Claudia Chemello, Christopher Watters and Peter Hull (eds.). Metal 2010, Proceedings of the Interim Meeting of the ICOM-CC Metal Working Group, Charleston, South Carolina, USA,11-15 October 2010. Clemson: Clemson University, 348-356.

Caley, R. 1955. In Studies in Conservation 2, 49-54.

Carradice, I. A., Campbell, S. A. 1994. In Studies in Conservation 39, 100-106.

Cronyn, J. M. 1990. The Elements of Archaeological Conservation. London: Routledge.

Degrigny, C. and Le Gall, R. 1999. In Studies in Conservation (44), 157-169.

Duncan, S. J., Ganiaris, H. 1987. In James Black (ed.). Recent Advances in the Conservation and Analysis of Artifacts: Jubilee Conservation Conference Papers. Michigan: Summer Schools Press, 109-117. 
Lane H. 1979. In The Conservation and Restoration of Metals. Scottish Society for Conservation and Restoration. Edinburgh, 48-58.

Nosek, E., M. 1985. In Studies in Conservation (30), 19-22.

Organ, R. M. 1953. In Museums Journal 53, 49-52.

Organ, R. M. 1977. In Brown, B.F., Burnett, H.C., Chase, W.T., Goodway, M., Kruger, J., and Poubaix, M. (eds). Corrosion and Metal Artefacts. Special publication 179. Washington, D.C.: National Bureau of Standards, 107-142.

Schotte B., Adriaens A. 2006. In Studies in conservation 51, 297-304.

Watson, J. 1985. In Lead and Tin: Studies in Conservation and Technology. UKIC Occasional Paper No 3. London: United Kingdom Institute for Conservation, 44-45.

\section{About the Author:}

Burshneva Svetlana G. Conservator of highest qualification, State Hermitage. Dvortsovaya Naberezhnaya (Embankment), 34, Saint Petersburg, 190000, Russian Federation; Institute of Archaeology named after A. Kh. Khalikov, Tatarstan Academy of Sciences. Butlerov Str., 30, Kazan, 420012, the Republic of Tatarstan, Russian Federation; burshneva@yandex.ru 